\title{
Bazı Herdem Yeşil Ağaçların Yapraklarının Görsel Algılanmasında Şekil ve Renk İlişkisinin Belirlenmesi
}

\author{
Selma KÖSA ${ }^{1}$ \\ ${ }^{1}$ Akdeniz Üniversitesi, Mimarlık Fakültesi, Peyzaj Mimarlığı Bölümü, 07070 ANTALYA
}

\section{Öz}

Bitkisel tasarımda bitki türlerinin doku ve renk etkisinde katkısı en fazla olan organları yapraklarıdır. Yapraklar, tasarım ilkeleri doğrultusunda mekanda birer tasarım öğesi olarak kullanıldığı gibi görsel algıya göre değerlendirilmeleri bitkisel tasarımlarda daha etkili ve başarılı sonuçlar yaratacaktır. Bu çalışmada, Antalya kent merkezinde bulunan Akdeniz Üniversitesi kampüsündeki herdem yeşil geniş yapraklı ağaçların yapraklarının görsel algılanmasında şekil ve renk ilişkisinin belirlenmesi amaçlanmıştır. Bu amaçla, 16 ağaç türüne ait yaprakların Ocak ayında çekilen fotoğrafları çalışma materyali olarak kullanılmıştır. Yaprakların kullanıcılar tarafindan anlamsal açıdan değerlendirilmesinde anlamsal farklılaşım tekniği ve kullanıcıların bazı kişisel özelliklerini belirlemeye yönelik soruları içeren bir anket kullanılmıştır. Çalışma sonucunda, yaprakların görsel algılanması ile yaprağın güzel ve etkileyici olma özelliği, yaprak şekli, yaprak rengi ve yaprak şekli ile renginin uyumu arasındaki ilişkiler istatistiksel anlamda önemli bulunmuştur. Ayrıca, kullanıcıların yaş ve cinsiyet özelliklerinin yaprakların görsel algılanmalarını önemli ölçüde etkilediği tespit edilmiştir. Sonuç olarak, herdem yeşil ağaç türlerinde, açık yeşil renge sahip oval, eliptik ve tek tüysü yaprak şeklindeki yaprakların görsel olarak iyi algılandıkları belirlenmiştir. Bitkisel tasarımlarda, herdem yeşil ağaçların yapraklarının görsel algılanmasında yaprak renk ve şekil ilişkilerinin etkili olduğu bilgisi göz önünde bulundurulmalıdır.

Anahtar Kelimeler: Yaprak, renk, şekil, görsel algı, Antalya.

\section{Determination of Shape and Color Relationship in the Visual Perception of the Leaves of Some Evergreen Trees}

\begin{abstract}
In planting design, the leaves have the most important contribution of plant species on texture and color effects. Leaves are used as a design element in the space according to design principles and their evaluations according to visual perception will create more effective and successful results in planting designs. In this study, it was aimed to determine the relationship between shape and color in the visual perception of the leaves of evergreen broadleaved trees at Akdeniz University campus in Antalya city center. For this purpose, photographs of 16 tree species in January were used as study material. In this respect, a questionnaire including the photographs of leaves of 16 tree species and the questions about determining some personal characteristics of the users and semantic differentiation technique for the semantic evaluation of the leaves by the users were used. As a result of the study, the relationship between the visual perception of beautiful and impressive feature of leaves, leaf shape, leaf color, leaf shape and color harmony was found to be statistically significant. In addition, it was determined that the age and gender characteristics of the users significantly affected the visual perception of the leaves. As a result, in evergreen tree species, light green color oval, elliptic and single leaves were found to be visually well perceived. In plant designs, it should be considered that leaf color and shape relations are effective in the visual perception of evergreen trees' leaves.
\end{abstract}

Keywords: Leaf, color, shape, visual perception, Antalya. 


\section{Giriş}

Peyzaj tasarımı yapılmış alanlarda zaman içerisinde alanın farklı şekillerde algılanmasında ve alanın kullanıcılar üzerinde farklı etkiler bırakmasında etkili olan en önemli tasarım materyali, canlı olma özelliği ile zaman içerisinde form, renk, doku ve ölçü özelliklerinde değişimler gösterebilen bitkilerdir. Peyzaj tasarımında bitkilerin ağırlıklı olarak ele alındığı alan ise bitki görünümleri ve kompozisyonudur (Altman ve Wohlwill, 1983;Nasar, 1988; Tarakçı Eren vd., 2018). Bitkisel tasarımda bitkiler başta estetik ve fonksiyonel olmak üzere ekolojik, psikolojik, sosyal ve ekonomik yararlar sağlamaları amacıyla kullanılmakta olup kullanıldıkları mekanlara bir çok fonksiyon katmaktadırlar. Bitkilerin bu fonksiyonları sağlamalarında, tasarımcılar tarafından bitkilerin bitkisel özelliklerinin ve ekolojik isteklerinin çok iyi bilinmesi yanında, bitkilerin veya bitkisel tasarımların insanlar üzerinde oluşturduğu görsel algının analiz edilmesi de önemli bir yer tutmaktadır. Elinç (2011), kullanıcı gereksinimlerini, beğeni ve tercihlerini esas alan çalışmalarda işlevsel beğeninin yanı sıra görsel beğeninin de öneminin vurgulandığını belirtmektedir. Literatürde bitki türlerinin veya bitkisel kompozisyonların görsel algılarını ve kullanıcı tercihlerini belirlemeye yönelik çok sayıda çalışma (Julan ve Yannjou, 1998; Acar ve ark. 2003; Müderrisoğlu ve Eroğlu, 2006; Müderrisoğlu ve ark. 2009; Kurdoğlu ve Pirselimoğlu, 2011; Sakıcı ve ark. 2012; Düzenli vd., 2018; Eroğlu ve Acar, 2018; Tarakçı Eren ve ark. 2018) yer almaktadır. Bu çalışmalar görsel algının bitki türlerinin ve bitkisel kompozisyonların kullanımında etkili olduğunu göstermektedir. Görsel algılama diğer algılar içinde en etkili ve en güçlü olandır (Kınık ve Öztürk, 2017). Görsel alg1, kalite değerinin duyular aracılığı ile insan beyninde yorumlanması olarak tanımlanmaktadır (Çakcı ve Çelem, 2009; Ak ve Kaya, 2016). Görsel algının ana elementlerinin şekil, renk, çizgi, 1şık, uzay ve yapı olduğu söylenebilmektedir (Kınık ve Öztürk, 2017). Psikolojik bir olgu olan görsel algı ile çevreden insana ulaşan görsel çevre etkenleri ilişkisi psikofizik yöntemlerle incelenmektedir. Görsel alg1 süreci, her algılanan objeye bağlı duygusal yük analizleri ve bilinçaltı seviyeleri ölçülerek kavranmaktadır (Aydınlı, 1986; Tüfekçioğlu, 2008; Basıç, 2016)

Bitki türlerinin veya bitkisel kompozisyonlarının görsel algılanmalarını belirlemeye yönelik yapılan çalışmalar, elde edilen kullanıcı tercihlerine ilişkin bilgilerin tasarımcılar tarafından planlama ve tasarım çalışmalarında kullanabilme firsatlarını sunmaktadır. Elinç (2011), kullanıcıların görsel tercihlerinin birçok değişkene bağımlı olduğunu ve kullanıcıların demografik profillerinin (yaş, cinsiyet, meslek, gelir v.b.) görsel tercihlerini önemli ölçüde etkilediğini bildirmektedir. Bitkilerin bitkisel tasarımda görsel açıdan etkili olmaları farklı özelliklerdeki birçok yapıya sahip olmalarından kaynaklanmaktadır. Bitkisel tasarımda bitki türlerinin doku ve renk etkisinde katkısı en fazla olan organı yapraklarıdır. Özellikle farklı mevsimlere göre değişebilen renklere sahip olan yapraklar, bitkisel tasarımda renk algısında etkili iken, zaman içerisinde büyüklüklerinde, şekillerinde ve renginde meydana gelen değişimlerle de doku üzerinde etkilidirler. Yapraklarda görülen mevsimsel renk değişimi sonbahar aylarında yaprak döken türlerle birlikte yoğun görülmekte olup, kış mevsiminde yapraklarda görülen renksel değişimi oldukça azalmakla birlikte sadece herdem yeşil ağaçların yaprak renklerinde sınırlı ölçüde gözlenmektedir. Herdem yeşil bitki türlerinde de sonbahar veya kış aylarında yaprak renklerinde değişim gözlenebilmektedir. Bu renk değişimi, mevcut yaprak renginden tamamen farklı bir renge dönüşüm şeklinde olabildiği gibi aynı zamanda, mevcut yaprak renginin farklı tonlarına dönüşüm şeklinde de olabilmektedir. Yaprak döken türlerde kışın bitkinin doku özelliği bitkinin dal ve dallanma yapısına bağlıyken, herdem yeşil bitkilerde doku özelliğinin belirlenmesinde en önemli faktör yaprak özellikleridir. Yaprak döken türlerin yapraksız olduğu kış mevsiminde herdem yeşil türlerin yaprak özellikleri daha çok dikkat çekmekte olup, bitkisel tasarımda algısal olarak daha farklı etkiler yaratabilmektedir. Yaprakların renk, şekil ve ölçü özellikleri bitki türlerine ve mevsimlerine göre farklılıklar göstermekte ve bitkisel tasarımda renk ve doku öğelerini tanımlamada etkili olmaktadırlar. Yapılan bazı çalışmalarda (Acar ve ark. (2003); Müderrisoğlu ve ark. (2009); Kösa ve Atik (2013); Tarakçı Eren ve ark. (2018) bitkisel tasarımlarda bitkilerin görsel algılanmasında veya tercihlerinde yaprak renklerinin etkili olduğu vurgulanmaktadır. Ancak, yapılan literatür taramasında, bitkilerin, bitkisel kompozisyonların veya yaprakların görsel algılanmasında yaprak renginin etkisini, yaprak şeklinin etkisini ve yaprak rengi ile yaprak şeklinin ilişkisini inceleyen herhangi bir çalışmaya rastlanmamıştır.

$\mathrm{Bu}$ çalışmada, Antalya kent merkezinde bulunan Akdeniz Üniversitesi kampüsündeki herdem yeşil geniş yapraklı ağaçların yapraklarının görsel algılanmasında şekil ve renk ilişkisinin belirlenmesi amaçlanmıştır.

\section{Materyal ve Yöntem}

\subsection{Materyal}

$\mathrm{Bu}$ çalışmada, Antalya Akdeniz Üniversitesi kampüsünde bitkisel tasarımda kullanılan 16 herdem yeşil geniş yapraklı ağacın yaprakları, bu yaprakların fotoğrafları ve çalışmanın amacına uygun olarak hazırlanan anket 
formları materyal olarak kullanılmıştır. Çalışmada kullanılan ağaç yapraklarının Ocak ayındaki şekillerine ve renklerine ilişkin görüntüleri Şekil 1'de yer almaktadır.

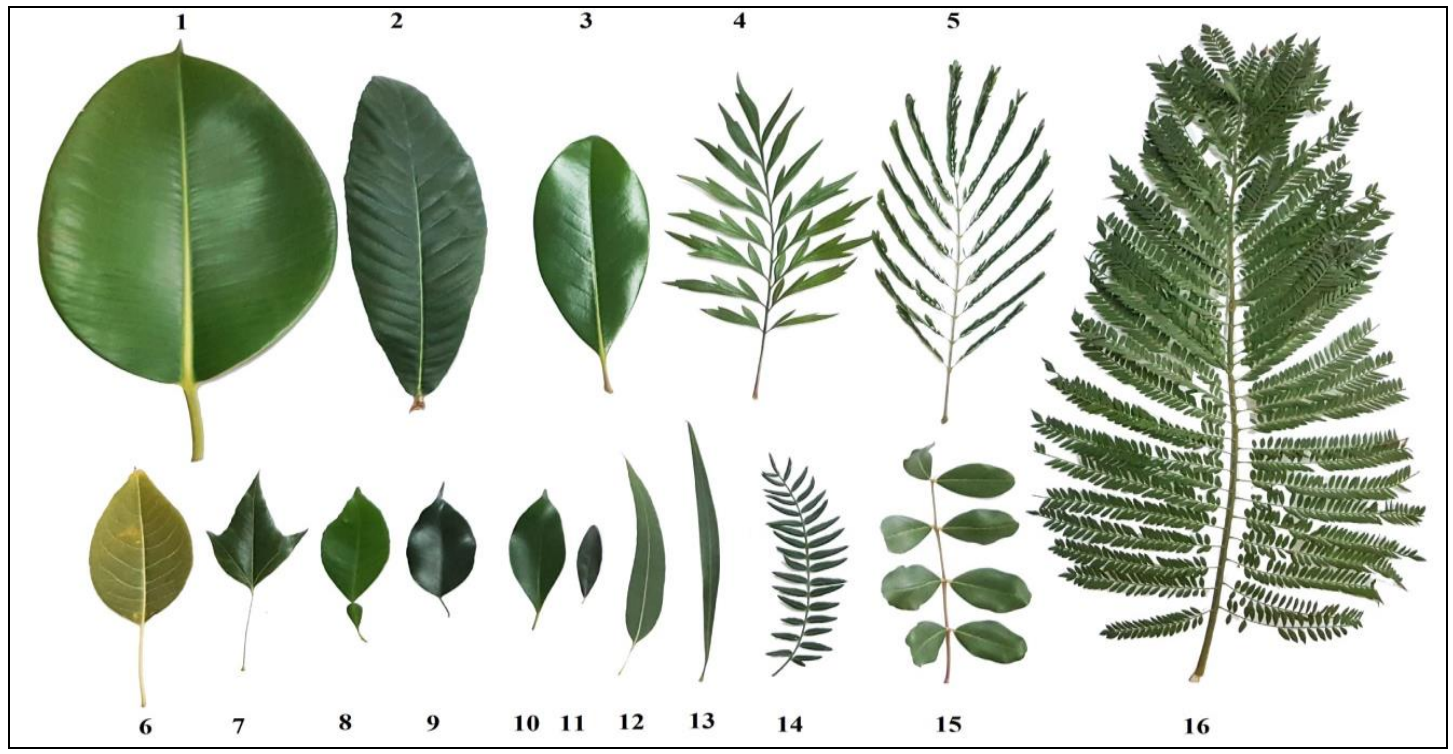

Şekil 1. Çalışmadaki 16 herdem yeşil ağacın Ocak ayındaki yapraklarının şekil ve renklerinin bir aradaki görüntüsü

(1: Ficus elastica Roxb. ex Hornem. , 2: Eriobotrya japonica (Thunb.) Lindl., 3: Magnolia grandiflora L., 4: Grevillea robusta A. Cum. ex R. Br., 5: Leucaena leucocephala, (Lam.) de Wit, 6: Phytolacca dioica L., 7: Brachychiton populneus (Schott \& Endlicher) Brown, 8: Citrus aurantium L.,, 9: Ficus benjamina L., 10: Ficus retusa L. 'Nitida', 11: Olea europaea L., 12: Eucalyptus camaldulensis DEHNH., 13: Acacia saligna (Labill.) H.L. Wendl., 14: Schinus molle L., 15: Ceratonia siliqua L., 16: Jacaranda mimosifolia D. Don)

\subsection{Yöntem}

Çalışma iki aşamadan oluşmaktadır. Birinci aşamayı çalışmada kullanılacak ağaçların ve yaprakların belirlenmesi, ikinci aşamayı ise yaprak özelliklerinden şekil ve rengin görsel algı üzerindeki etkisinin belirlenmesi amacıyla gerçekleştirilen anket uygulaması oluşturmaktadır. Çalışmanın birinci aşamasında, Ocak ayı ortasında kampüste yaprak dökmeyen odunsu geniş yapraklı ağaç türleri bitkisel tasarım yapılmış alanlar incelenerek kampüste 16 adet herdem yeşil geniş yapraklı ağaç türü tespit edilmiştir. Herdem yeşil olarak çalışma kapsamına alınan ağaç türlerinin hepsi Antalya koşullarında herdem yeşil özellik göstermektedirler. Ağaç türlerinin tipik tür özellikleri gösteren yaşta, boyutta ve formda olan bireylerinden yaprak örnekleri alınmış, alınan bu örneklerin karşılaştırılmasıyla ortalama büyüklüklere en yakın birer yaprak araştırmada materyal olarak kullanılmak üzere o türleri temsil eden yapraklar olarak seçilmiştir. Belirlenen ağaç türleri yaprak şekillerine göre, bileşik yapraklı ve basit yapraklı olmak üzere iki ana gruba ayrılmış ve yaprak şekilleri basit yapraklılarda ve bileşik yapraklılarda ayrı ayrı belirlenmiştir. Türlere göre yaprak şekilleri Tablo 1'de verilmiştir. Türlerin hepsinin Ocak ayındaki yaprak renkleri yeşil olmakla birlikte yeşilin tonlarında farklılıklar göstermektedir. Yaprakların mevcuttaki rengini ve şeklini gösterecek şekilde tüm yaprakların bir arada ve ayrı ayrı olacak şekilde fotoğrafları çekilmiştir. Tüm türlerin yaprakları aynı gün aynı saatte, 16 megapiksel çözünürlüğe sahip aynı dijital kamera ile fotoğraflanmıştır.

Tablo 1. Bitki tür isimlerine göre yaprak şekilleri

\begin{tabular}{|c|c|c|c|}
\hline \multicolumn{2}{|c|}{ Basit Yapraklı Türler } & \multicolumn{2}{|c|}{ Bileşik Yaprakı Türler } \\
\hline Tür İsimleri & $\begin{array}{l}\text { Yaprak } \\
\text { Şekilleri }\end{array}$ & Tür İsimleri & Yaprak Şekilleri \\
\hline Acacia saligna & Mizraks1 & Ceratonia siliqua & Çift tüysü \\
\hline Brachychiton populneus & Üç loblu & Grevillea robusta & Tek tüysü \\
\hline Citrus aurantium & Oval & Jacaranda mimosifolia & İki katlı tek tüysü \\
\hline Eriobotrya japonica & Eliptik & Leucaena leucocephala & İki katlı çift tüysü \\
\hline Eucalyptus camaldulensis & Mizraks1 & Schinus molle & Tek tüysü \\
\hline Ficus benjamina & Oval & & \\
\hline Ficus elastica & Oval & & \\
\hline Ficus retusa 'Nitida' & Oval & & \\
\hline Magnolia grandiflora & Eliptik & & \\
\hline Olea europaea & Eliptik & & \\
\hline Phytolacca dioica & Oval & & \\
\hline
\end{tabular}


Çalışmanın ikinci aşamasında yer alan anket uygulamasında 16 ağaç türünün her birine ait yapraklarının fotoğrafları anket aracıllğı ile deneklere gösterilerek yaprakların görsel algılanmasında yaprak şekil ve yaprak renk etkisinin tespit edilmesi ve farklı herdemyeşil ağaç yapraklarının görsel algılanma düzeylerinin belirlenmesi amaçlanmıştır. Bu amaç için anket ile Anlamsal Farklılaşım Ölçeği tekniği kullanılmış ve "Yaprak şekli ile rengi uyumlu/Yaprak şekli ile rengi uyumsuz", "Yaprak şekli etkili/Yaprak şekli etkisiz", "Yaprak rengi etkili/Yaprak rengi etkisiz", "Etkileyici/Etkileyici değil", "Güzel/Güzel değil", olmak üzere 5 sıfat çifti yardımıyla yaprakların görsel algılanmasındaki farklılıklar ortaya konulmuştur. Bu sıfat çiftlerinin belirlenmesi, anket yönteminin belirlenmesi ve uygulanmasında, Acar ve ark. (2003), Müderrisoğlu ve Eroğlu (2006), Kurdoğlu ve Pirselimoğlu (2011), Çakıcı ve ark. (2012), Sarı ve Karaşah (2015), Ak ve Kaya (2016), Kurdoğlu ve Üstün Topal (2017) ve Düzenli ve ark. (2018) ve Tarakçı Eren ve ark. (2018),'nin çalışmalarından yararlanılmıştır. Anket formlarına yerleştirilen 16 türün yapraklarını deneklerden ayrı ayrı değerlendirmeleri için her bir sıfat çifti için “- $3,-2,-1,0,1,2,3$ ” değerlerinden birini işaretlemeleri istenmiştir. Bu ölçekte (-) değerler olumsuz olup (-1)den (-3)' e doğru olumsuzluk derecesi artmakta; $(+)$ değerler ise olumlu olup $(+1)$ den (+3)'e doğru olumluluk derecesi artmaktadır. (0) ise nötr düşünceyi ifade etmektedir. Anket sonuçlarının değerlendirilmesinde kolaylıklar sağlaması açısından ölçek üzerindeki bu rakamlar 1-7 rakamlarına dönüştürülmüştür. Beş sıfat çiftlerinin aldığı puanların aritmetik ortalaması hesaplanarak her yaprağın görsel algılanma puanları belirlenmiştir. Çalışmada kullanılan Anlamsal Farklılaşım Ölçeği Tablo 2'de verilmiştir.

Yaprakların görsel algılanmasında yaprak rengi ve yaprak şeklinin etkisini belirlemek amacıyla kullanılan bu sıfat çiftlerinin ifade ettiği anlamlar yorumlanırken, "Yaprak şekli ile rengi uyumlu/Yaprak şekli ile rengi uyumsuz" sıfat çifti, "yaprak şekli ile yaprak rengi uyumluluğu" şeklinde, "Yaprak şekli etkili/Yaprak şekli etkisiz" sıfat çifti, "yaprak şekli etkililiği”" şeklinde, "Yaprak rengi etkili/Yaprak rengi etkisiz" sıfat çifti, "yaprak rengi etkililiği”" şeklinde, "Etkileyici/Etkileyici değil" sıfat çifti, "yaprak etkileyiciliği”" şeklinde ve "Güzel/ Güzel değil" sıfat çifti ise, "yaprak güzelliği” şeklinde ifade edilmiştir. Anket çalışmasında Akdeniz Üniversitesi Peyzaj Mimarlığı bölümü öğrencilerinden bitkisel tasarım dersini almış olan 65 (dersi alan tüm öğrenci sayısı) öğrenci denek olarak seçilmiştir. Anketler öğrencilere 2 farklı grup halinde yapılmış olup, bitki türlerine ait foroğraflar projeksiyon cihazı ile yansıtılmış ve ellerine verilen anket formlarında yer alan tablolara puanlamaları yapmaları istenmiş̧tir. Her türün yapraklarını gösteren fotoğraflara ayrı slaytta yer verilerek her tür için bir slayt kullanılmış olup, deneklerin her fotoğrafi inceleyerek 20-30 sn sürede değerlendirmeleri ve ellerine verilen anket formlarında puanlamaları işaretleyerek yapmaları sağlanmıştır. Her grup için toplam 16 türe verilen anket süresi en az $16 \mathrm{dk}$ en fazla ise $24 \mathrm{dk}$ olmuştur.

Tablo 2. Araştırmada kullanılan anlamsal farklılaşım ölçeği

\begin{tabular}{lllllllll}
\hline Değerlendirme Sıfatları & $\mathbf{3}$ & $\mathbf{2}$ & $\mathbf{1}$ & $\mathbf{0}$ & $\mathbf{- 1}$ & $\mathbf{- 2}$ & $\mathbf{- 3}$ & Değerlendirme Sıfatları \\
& $\mathbf{( 7 )}$ & $\mathbf{( 6 )}$ & $\mathbf{( 5 )}$ & $\mathbf{( 4 )}$ & $\mathbf{( 3 )}$ & $\mathbf{( 2 )}$ & $\mathbf{( 1 )}$ & \\
\hline Yaprak şekli ile rengi uyumlu & $*$ & $*$ & $*$ & $*$ & $*$ & $*$ & $*$ & Yaprak şekli ile rengi uyumlu değil \\
Yaprak şekli etkili & $*$ & $*$ & $*$ & $*$ & $*$ & $*$ & $*$ & Yaprak şekli etkili değil \\
Yaprak rengi etkili & $*$ & $*$ & $*$ & $*$ & $*$ & $*$ & $*$ & Yaprak rengi etkili değil \\
Etkileyici & $*$ & $*$ & $*$ & $*$ & $*$ & $*$ & $*$ & Etkileyici değil \\
Güzel & $*$ & $*$ & $*$ & $*$ & $*$ & $*$ & $*$ & Güzel değil \\
\hline
\end{tabular}

Görsel değerlendirme konularına yönelik araştırmalar çoğunlukla anlamsal farklılaşım metodu çerçevesinde çeşitli nitelikler (sıfatlar) açısından kişilerin görüntüye verdikleri puanları esas almakta ve irdeleme yapmaktadır (Shafer ve Richards, 1974; Sanoff, 1991; Kaptanoğlu, 2006). Osgood ve ark. (1975) tarafindan geliştirilen anlamsal farklılaşım ölçeği, çevresel psikoloji alanında kullanılan yaygın bir yöntem olup çevre ile gözlemci arasındaki etkileşimi ölçmek, öznel ve çevresel reaksiyonları incelemek amacıyla faydalanılan bir yöntemdir (Acar ve ark. 2003; Sakıcı ve Var, 2014; Kurdoğlu ve Üstün Topal, 2017). Küller (1972) ise anlamsal farklılaşmayı, estetik anlamın ölçülmesi amacı ile kullanılan bir teknik olarak nitelendirmektedir. Çalışma sonucunda, elde edilen verilerin istatistiksel anlamda değerlendirilmesinde SPSS programı kullanılmış olup, yaprak özelliklerinin birbirleriyle ve görsel algı ile ilişkilerinin belirlenmesinde ve ankete katılan öğrencilerin kişisel özelikleri ile yaprak özelliklerine verilen puanlar arasındaki ilişkilerin belirlenmesinde Korelasyon analizinden yararlanılmıştır.

\section{Bulgular ve Tartışma}

\subsection{Demografik özellikler}

Ankete katılan 65 öğrenciden 46'sı kadın 19'u erkektir. Deneklerin yaş gruplarına göre kişi sayıları değerlendirildiğinde, 19 yaşında 1, 20 yaşında 13, 21 yaşında 11, 22 yaşında 11, 23 yaşında 16, 24 yaşında 7, 25 yaşında 1 ve 26 yaşında ise 3 kişi yer almaktadır. 


\subsection{Bitki türlerinin yaprak özelliklerine göre görsel algılanmasındaki farklılıklar}

Tablo 3'de sıfat çiftlerine göre bitki türlerinin yapraklarına yapılan puanlamaların aritmetik ortalamaları görülmektedir. Sıfat çiftlerine göre türlere verilen puanlar değerlendirildiğinde, görsel olarak en iyi algılanan tür Ficus elastica olarak belirlenmiştir. Ficus elastica türü aynı zamanda yaprak rengi ile şekli en uyumlu, yaprak rengi en etkili, yaprağı en etkileyici ve yaprağı en güzel tür olarak tespit edilmiştir. Brachychiton populneus türü yaprak şekli en etkili tür olarak belirlenmiş ve görsel algılanması en yüksek türler sıralamasında 6 . sırada yer almıştır. Görsel algılanması yüksek diğer türler incelendiğinde ise Magnolia grandiflora 2.sırada, Grevillea robusta 3. sirada, Citrus aurantium 4. sirada, Jacaranda mimosifolia 5. sırada görülmektedir. Acacia saligna görsel algılanması en düşük tür olarak belirlenmiş, aynı zamanda bu tür yaprak rengi en etkili türler sıralamasında ve yaprağı genel olarak en etkili ve en güzel türler sıralamasında sonuncu sırada yer almıştır. Görsel algılanma puanı en düşük diğer türler ise Phytolacca dioica, Olea europaea ve Leucaena leucocephala'dır (Tablo 3, Şekil 2).

Tablo 3: Türlerin sıfat çiftlerine göre aldıkları puanların aritmetik ortalamaları ve görsel algılanma puanları

\begin{tabular}{|c|c|c|c|c|c|c|}
\hline \multirow[b]{2}{*}{ Bitki Tür İsimleri } & \multicolumn{6}{|c|}{ Sifat Çiftleri } \\
\hline & $\begin{array}{l}\text { Yaprak şekli ile } \\
\text { rengi } \\
\text { uyumlu/Yaprak } \\
\text { şekli ile rengi } \\
\text { uyumsuz }\end{array}$ & $\begin{array}{l}\text { Yaprak şekli } \\
\text { etkili/Yaprak } \\
\text { şekli etkisiz }\end{array}$ & $\begin{array}{l}\text { Yaprak rengi } \\
\text { etkili/Yaprak } \\
\text { rengi etkisiz }\end{array}$ & $\begin{array}{l}\text { Etkileyici/ } \\
\text { Etkileyici } \\
\text { değil }\end{array}$ & $\begin{array}{l}\text { Güzel/ } \\
\text { Güzel } \\
\text { değil }\end{array}$ & $\begin{array}{l}\text { Görsel } \\
\text { Algılanma }\end{array}$ \\
\hline Acacia saligna & 5,14 & 5,11 & 4,57 & 4,54 & 4,54 & 4,78 \\
\hline $\begin{array}{l}\text { Brachychiton } \\
\text { populneus }\end{array}$ & 5,54 & 6,22 & 5,38 & 5,45 & 5,43 & 5,60 \\
\hline Citrus aurantium & 5,71 & 6,02 & 5,48 & 5,66 & 5,54 & 5,68 \\
\hline Eriobotrya japonica & 5,80 & 5,31 & 5,49 & 5,37 & 5,40 & 5,47 \\
\hline $\begin{array}{l}\text { Eucalyptus } \\
\text { camaldulensis }\end{array}$ & 5,48 & 5,49 & 5,34 & 5,26 & 5,37 & 5,39 \\
\hline Ficus benjamina & 5,22 & 5,31 & 5,31 & 5,29 & 5,38 & 5,30 \\
\hline Ficus elastica & 6,11 & 6,14 & 6,00 & 6,14 & 6,11 & 6,10 \\
\hline Ficus retusa 'Nitida' & 5,26 & 5,43 & 5,35 & 5,28 & 5,35 & 5,34 \\
\hline Magnolia grandiflora & 5,95 & 5,89 & 5,88 & 5,86 & 6,03 & 5,92 \\
\hline Olea europaea & 5,00 & 5,08 & 4,91 & 4,92 & 4,86 & 4,95 \\
\hline Phytolacca dioica & 4,86 & 5,06 & 4,86 & 4,72 & 4,66 & 4,83 \\
\hline Ceratonia siliqua & 5,75 & 5,46 & 5,57 & 5,28 & 5,42 & 5,50 \\
\hline Grevillea robusta & 5,78 & 6,15 & 5,69 & 5,65 & 5,74 & 5,80 \\
\hline Jacaranda mimosifolia & 5,51 & 5,94 & 5,51 & 5,52 & 5,58 & 5,61 \\
\hline $\begin{array}{l}\text { Leucaena } \\
\text { leucocephala }\end{array}$ & 5,12 & 5,15 & 5,22 & 4,83 & 5,05 & 5,07 \\
\hline Schinus molle & 5,42 & 5,52 & 5,28 & 5,35 & 5,23 & 5,36 \\
\hline
\end{tabular}

Türlerin yapraklarının görsel algılanmaları yaprak renklerine ve şekillerine göre değerlendirildiğinde, hem basit yapraklarda hem de bileşik yapraklarda diğerlerine göre daha açık yeşil tonlarındaki yaprakların görsel algılanması daha yüksek çıkmıştır. Türlerin görsel algılanma sıralamasındaki yerleri, yaprak şekli en etkili türler ve yaprak rengi en etkili türler sıralamasındaki yerleri ile benzerlik göstermektedir. Bu sonuç, yaprakların görsel algılanmasında yaprak rengi ile yaprak şeklinin etkili olduğunu, aynı zamanda yaprak şeklinin etkili olarak algılanmasında yaprak renginin etkisinin olduğunu, yaprak renginin etkili olarak algilanmasında yaprak şeklinin etkili olduğunu göstermektedir (Tablo 3). Yaprak özelliklerinin kendi aralarındaki ilişkileri ve yaprak özellikleri ile görsel algılanmaları arasındaki ilişkilerin istatistiksel anlamda değerlendirilmesinde elde edilen sonuçlar da bu bilgileri doğrulamaktadır. Yapılan istatistiksel analiz sonucunda, yaprak şekli ile yaprak rengi uyumluluğu, yaprak rengi etkililiği, yaprak şekli etkililiği, yaprak etkileyiciliği ve yaprak güzelliği olmak üzere tüm yaprak özellikleri arasındaki ilişkiler ve bu yaprak özellikleri ile yaprakların görsel algılanma puanları arasındaki ilişkiler istatistiksel anlamda \% 1 düzeyinde önemli bulunmuştur (Tablo 4). 


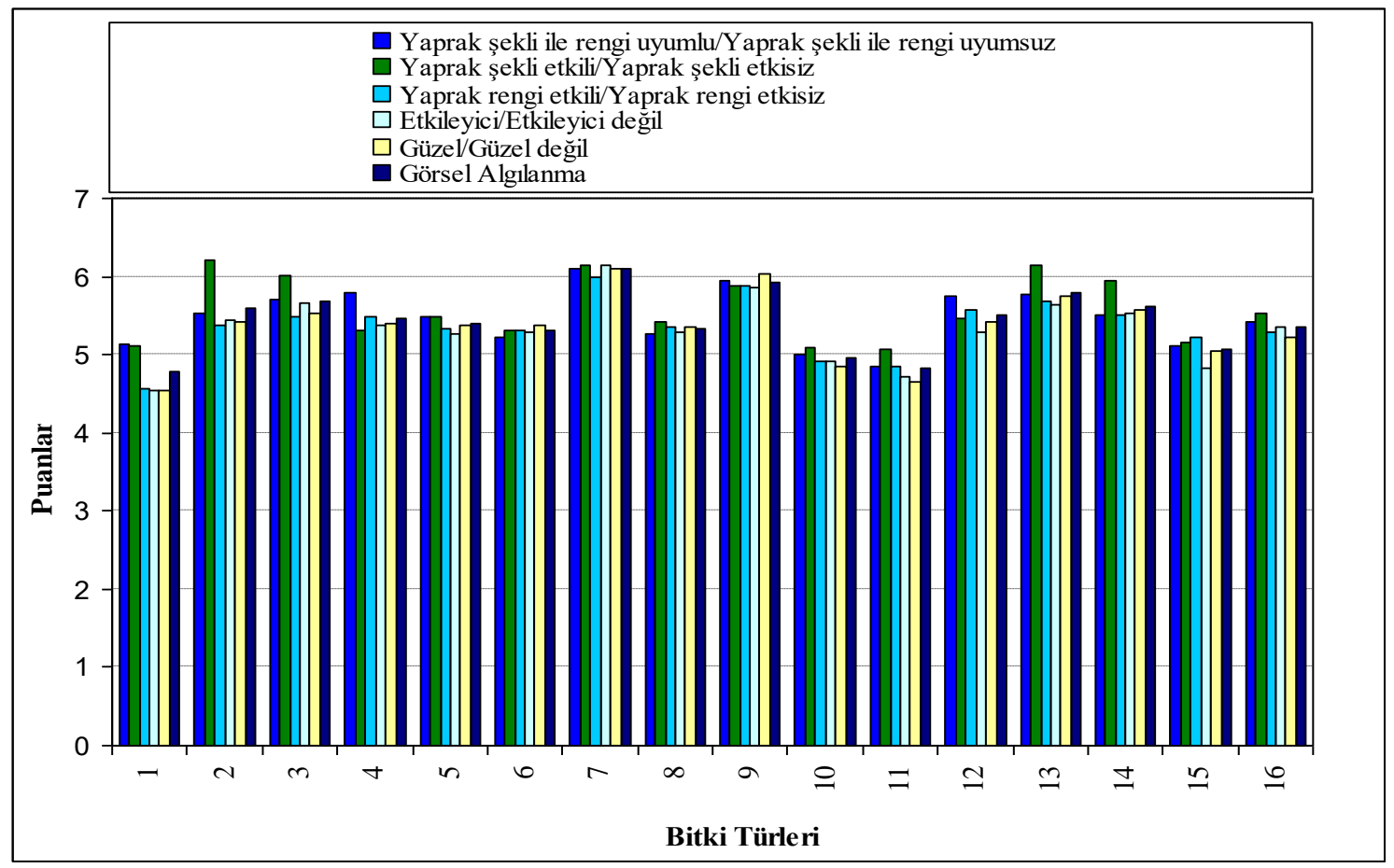

Şekil 2. Bitki türlerinin sıfat çiftleri ve görsel algılanma puanları

Bitki Türleri; 1:Acacia saligna, 2:Brachychiton populneus 3:Citrus aurantium 4:Eriobotrya japonica 5:Eucalyptus camaldulensis 6: Ficus benjamina 7: Ficus elastica 8: Ficus retusa 'Nitida' 9: Magnolia grandiflora 10:Olea europaea 11:Phytolacca dioica 12:Ceratonia siliqua 13:Grevillea robusta 14: Jacaranda mimosifolia 15:Leucaena leucocephala 16:Schinus molle

Tablo 4: Sıfat çiftleri ile görsel algılanma puanları arasındaki ilişkileri gösteren spearman korelasyon katsayıları

\begin{tabular}{llllll}
\hline Sıfat Çiftleri & $\begin{array}{l}\text { Yaprak şekli ile rengi } \\
\text { uyumlu/Yaprak şekli ile } \\
\text { rengi uyumsuz }\end{array}$ & $\begin{array}{l}\text { Yaprak şekli } \\
\text { etkili/Yaprak } \\
\text { şekli etkisiz }\end{array}$ & $\begin{array}{l}\text { Yaprak rengi } \\
\text { etkili/Yaprak } \\
\text { rengi etkisiz }\end{array}$ & $\begin{array}{l}\text { Etkileyici/ } \\
\text { Etkileyici } \\
\text { değil }\end{array}$ & $\begin{array}{l}\text { Güzel/ } \\
\text { Güzel } \\
\text { değil }\end{array}$ \\
\hline $\begin{array}{l}\text { Yaprak şekli etkili/Yaprak } \\
\text { şekli etkisiz }\end{array}$ & $0,756\left(^{* *}\right)$ & & & & \\
$\begin{array}{l}\text { Yaprak rengi } \\
\text { etkili/Yaprak rengi etkisiz }\end{array}$ & $0,891\left(^{* *}\right)$ & $0,751\left(^{* *}\right)$ & & & \\
$\begin{array}{l}\text { Etkileyici/ Etkileyici değil } \\
\text { Güzel/ Güzel değil }\end{array}$ & $0,885\left(^{* *}\right)$ & $0,851\left(^{* *}\right)$ & $0,941\left(^{* *}\right)$ & & \\
Görsel algılanma & $0,98\left(^{* *}\right)$ & $0,808\left(^{* *}\right)$ & $0,980\left(^{* *}\right)$ & $0,972\left(^{* *}\right)$ & $0,982\left(^{* *}\right)$ \\
\hline
\end{tabular}

**: Korelasyon 0,01 düzeyinde önemli

En yüksek görsel algılanma puanına sahip olan Ficus elastica türü, açık yeşil tonlarında bir renge ve basit oval yaprak şekline sahiptir. En yüksek görsel algılanma sıralamasında 2. sırada yer alan Magnolia grandiflora türü, açık yeşil renge ve basit eliptik yaprak şekline sahiptir. 3. sırada yer alan Grevillea robusta türü, açık yeşil renge ve bileşik tek tüysü yaprak şekline sahiptir. Türlerin yapraklarının görsel algılanmaları yaprak şekil ve renk ilişkilerine göre değerlendirildiğinde, oval, eliptik ve tek tüysü yaprak şekillerine sahip yaprakların görsel algılanmaları daha yüksek bulunmuş ve bu yaprak şekillerine sahip yaprakların açık yeşil renk tonlarına sahip olanlarının daha koyu yeşil renk tonlarına sahip olan yapraklara göre görsel algılanmalarının daha yüksek olduğu belirlenmiştir (Şekil 3). 


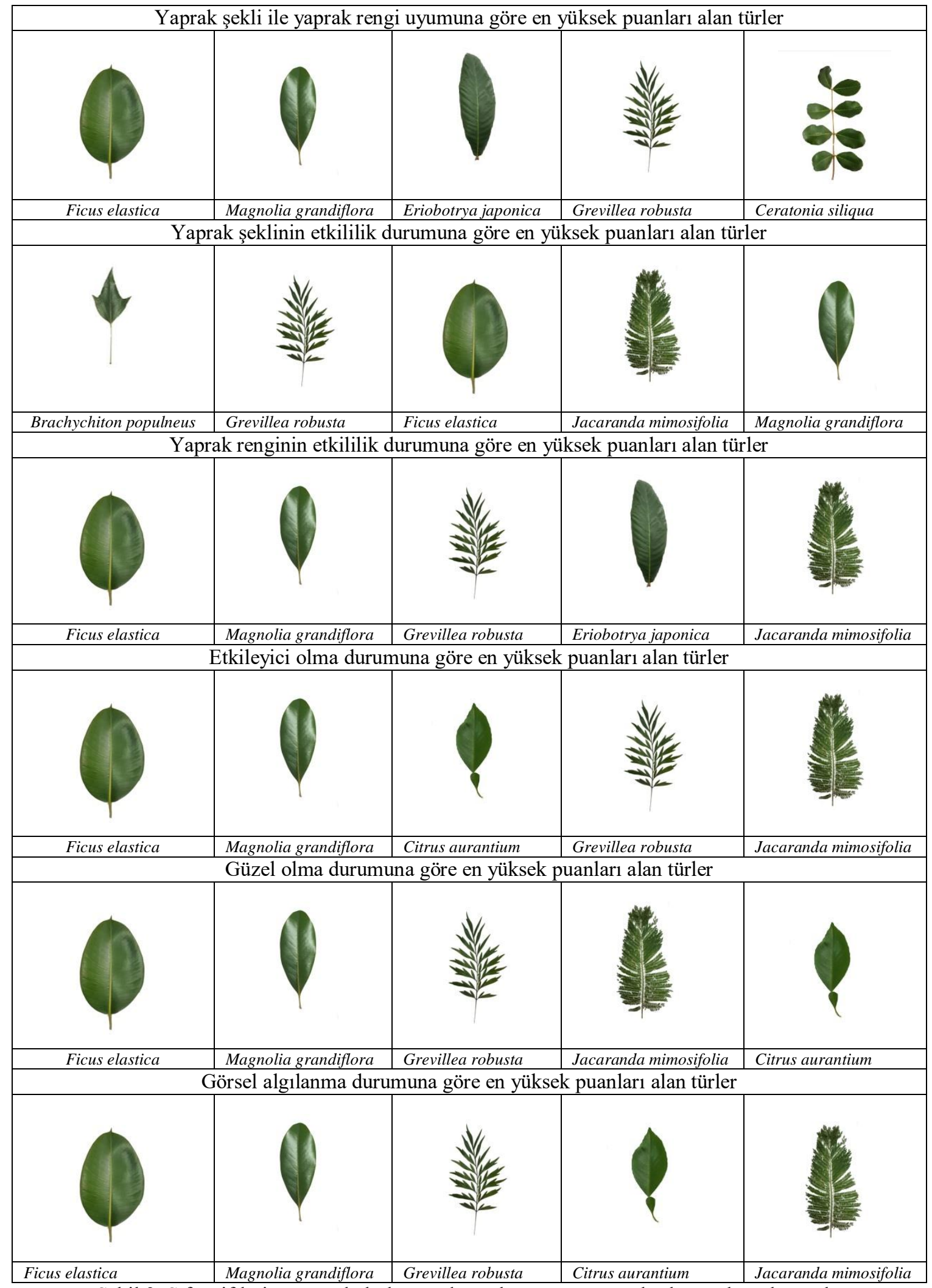

Şekil 3. Sıfat çiftleri ve görsel algılanma durumlarına göre en yüksek puanları alan türler

Bu sonuç, Öngen (2011)'in biçimdeki rengin güçlendikçe daha dikkat çekici olduğu yönündeki ifadeleri ile benzerlik göstermektedir. Çalışma sonucunda, tüm türlerin yapraklarında çoğunlukla daha parlak ve canlı olan açı yeşil renkli yaprakların görsel algılanmalarının daha yüksek olarak tespit edilmiştir. Hemphill (1996), parklar renklerin mutluluk, sevinç ve umut gibi olumlu duygular ile ilişkili olduğunu, Kınık ve Öztürk (2017) ise renklerin, tür, değer, doygunluklarına göre değişen sıcaklık, soğukluk, aktiflik, pasiflik, hafiflik, uyarıcılık ve dinlendiricilik gibi özelliklerinin sevinç ve üzüntü gibi pek çok psikolojik etkileri olduğu bildirmektedir. 
Çalışma sonucunda, türler genel olarak yaprak güzelliğine göre değerlendirildiklerinde yaprak şekilleri oval, uzun ve büyük boyutlardaki yapraklar daha güzel olarak algılanmıştır. Bu sonuca benzer şekilde, Zhao ve ark. (2017) insanlar tarafindan ağaçların güzel olarak algılanmasında yaprak boyutlarının etkili olduğunu belirtmektedir.

\subsection{Katılımcıların demografik özellikleri ile yaprakların görsel algılanması ilişkisi}

Türlerin yaprak şekli etkililiği dışındaki diğer tüm yaprak özellikleri ile deneklerin yaşları arasındaki ilişkiler istatistiksel anlamda negatif yönde \% 5 düzeyinde önemli bulunurken, deneklerin cinsiyetleri ile türlerin tüm yaprak özellikleri arasındaki ilişkiler ise negatif yönde \% 1 düzeyinde önemli bulunmuştur (Tablo 5). Bunun anlamı ise, en küçük yaş olan 19 yaşında, yaprak özelliklerine verilen puanlar en yüksek iken en büyük yaş olan 26 yaşında ise verilen puanlar en düşüktür. Tüm yaprak özelliklerine erkeklerin verdiği puanlar kadınların verdiği puanlardan daha düşüktür (Tablo 6).

Tablo 5. Deneklerin demografik özellikleri ile sıfat çiftlerine verilen puanlar arasındaki ilişkileri gösteren spearman korelasyon katsayıları

\begin{tabular}{|c|c|c|c|c|c|}
\hline \multirow[b]{2}{*}{$\begin{array}{c}\text { Demografik } \\
\text { Özellikler }\end{array}$} & \multicolumn{5}{|c|}{ Sıfat Çiftleri } \\
\hline & $\begin{array}{l}\text { Yaprak şekli ile rengi } \\
\text { uyumlu/Yaprak şekli } \\
\text { ile rengi uyumsuz }\end{array}$ & $\begin{array}{l}\text { Yaprak şekli } \\
\text { etkili/Yaprak } \\
\text { şekli etkisiz }\end{array}$ & $\begin{array}{l}\text { Yaprak rengi } \\
\text { etkili/Yaprak } \\
\text { rengi etkisiz }\end{array}$ & $\begin{array}{l}\text { Etkileyici/ } \\
\text { Etkileyici } \\
\text { değil }\end{array}$ & $\begin{array}{l}\text { Güzel/ } \\
\text { Güzel } \\
\text { değil }\end{array}$ \\
\hline Yaş & $-0,340\left(^{*}\right)$ & $-0,178$ & $-0,329\left(^{*}\right)$ & $-0,338(*)$ & $-0,344\left(^{*}\right)$ \\
\hline Cinsiyet & $-0,430(* *)$ & $-0,343\left(^{*}\right)$ & $-0,468(* *)$ & $-0,401(* *)$ & $-0,371(* *)$ \\
\hline
\end{tabular}

**, *: Korelasyon sırasıyla 0.01 ve 0.05 olasılık düzeylerinde önemli.

Tablo 6. Demografik özelliklere göre sıfat çiftleri puanları

\begin{tabular}{|c|c|c|c|c|c|}
\hline \multirow[b]{2}{*}{$\begin{array}{c}\text { Demografik } \\
\text { Özellikler }\end{array}$} & \multicolumn{5}{|c|}{ Sıfat Çiftleri } \\
\hline & $\begin{array}{l}\text { Yaprak şekli ile rengi } \\
\text { uyumlu/Yaprak şekli ile } \\
\text { rengi uyumsuz }\end{array}$ & $\begin{array}{l}\text { Yaprak şekli } \\
\text { etkili/Yaprak } \\
\text { şekli etkisiz }\end{array}$ & $\begin{array}{l}\text { Yaprak rengi } \\
\text { etkili/Yaprak } \\
\text { rengi etkisiz }\end{array}$ & $\begin{array}{l}\text { Etkileyici/ } \\
\text { Etkileyici } \\
\text { değil }\end{array}$ & $\begin{array}{l}\text { Güzel/ } \\
\text { Güzel } \\
\text { değil }\end{array}$ \\
\hline \multicolumn{6}{|c|}{ 3 } \\
\hline 19 & 6,19 & 5,25 & 5,38 & 5,38 & 5,38 \\
\hline 20 & 5,54 & 5,63 & 5,62 & 5,62 & 5,66 \\
\hline 21 & 5,90 & 5,61 & 5,55 & 5,55 & 5,59 \\
\hline 22 & 5,65 & 5,46 & 5,29 & 5,29 & 5,41 \\
\hline 23 & 5,50 & 5,23 & 5,23 & 5,23 & 5,32 \\
\hline 24 & 5,17 & 4,74 & 4,58 & 4,58 & 4,64 \\
\hline 25 & 5,25 & 4,88 & 4,56 & 4,56 & 4,75 \\
\hline 26 & 5,46 & 4,77 & 5,03 & 5,03 & 4,80 \\
\hline \multicolumn{6}{|l|}{ Cinsiyet } \\
\hline Kadın & 5,76 & 5,79 & 5,63 & 5,54 & 5,58 \\
\hline Erkek & 5,09 & 5,24 & 4,88 & 4,93 & 5,00 \\
\hline
\end{tabular}

Türlerin yaprak özelliklerine göre kişilerin algıları ayrı ayrı değerlendirildiğinde, yaş ve cinsiyet özellikleri yaprakların görsel algılanmasını olumlu veya olumsuz yönde etkilemiştir. Bu sonuca benzer şekilde, Müderrisoğlu ve Eroğlu (2006) kişilerin karakteristik özelliklerinin ağaç formlarının görsel algılanması üzerine etkili olduğunu belirlemişlerdir. Bu sonuca aynı zamanda, kişilerin renk seçimini yaş, cinsiyet ve çevre koşullarının etkilediği( Kınık ve Öztürk ,2017), hayatımız boyunca edindiğimiz deneyimlerin görsel algıda etkili olacağı (Müderrisoğlu ve Eroğlu, 2006), renk duygu ve tercihini yaşın etkilediği (Ou ve ark., 2012), bilgileri de benzerlik göstermektedir. Ayrıca çalışmada, daha parlak özellik gösteren açık yeşil renge sahip yaprakların görsel algılanması kadınlar tarafından daha yüksek bulunmuştur. Bu sonuca benzer olarak Hemphill (1996), parlak renklere kadınların erkeklere göre daha olumlu tepkiler verdiğini belirtmektedir. Bunun yanında, insanların renklere karşı farklı tepkiler vermesinde, kişilik oluşumları, eğitim durumları, bilinç altında bastırılmış olan duygular gibi bir çok nedenin olduğu ifade edilmektedir (Özdemir, 2005) 


\section{Sonuç ve Öneriler}

Çalışmada, Akdeniz Üniversitesi kampüsünde bulunan 16 herdem yeşil ağaçtan Ocak ayında toplanan yaprakları 65 kişi tarafından yaprak şekli ile rengi uyumluluğu, yaprak şekli etkililiği, yaprak rengi etkililiği, yaprağın genel etkililiği ve yaprağın genel güzelliği bakımından değerlendirilmiş ve yaprakların tüm bu özellikleri ile görsel algılanmaları arasındaki ilişkilerin istatistiksel anlamda önemli olduğu tespit edilmiştir. Bir başka ifadeyle ise, yaprakların görsel algılanmasında yaprak şeklinin, yaprak renginin ve yaprak rengi ile şeklinin uyumunun etkili olduğu ortaya konulmuştur. 16 herdem yeşil ağaç türünün yaprak renklerinin yeşilin tonlarında farklılıklar göstermesi, aynı zamanda yaprak şekilleri itibariyle de farklılıklar göstermesine rağmen, çoğunlukla açık yeşil renk tonuna sahip yaprakların görsel algılanma puanlarının yüksek olması kullanıcıların, herdem yeşil türlerde açık yeşil yaprak renklerini daha iyi algıladıkları sonucunu ortaya koymaktadır.

Demografik özelliklerin bitki türlerinin ve bitkisel kompozisyonların görsel algılanması üzerinde etkili olabildiği önceki çalışmalardan bilinmektedir. Bu çalışma, herdem yeşil ağaçların yapraklarının görsel algılanmasında kullanıcıların yaş ve cinsiyet özelliklerinin etkili olduğu bilgisini bilinen bu bilgilere ilave etmektedir.

$\mathrm{Bu}$ çalışma, basit ve bileşik yapraklı herdem yeşil ağaçların Ocak ayında açık yeşil renge sahip yapraklarının daha iyi algılandığı bilgisini tasarımcıların kullanımına sunmaktadır. Ayrıca herdem yeşil ağaçların yapraklarının görsel algılanmasının yaprak şekli ve yaprak rengine göre değiştiği; oval, eliptik ve tek tüysü yaprak şekillerine sahip yaprakların daha iyi algılandığı, bu yaprak şekillerine sahip türlerin yapraklarının açık yeşil renk tonlarına sahip olanlarının daha koyu yeșil renk tonlarına sahip olanlarının yapraklarına göre daha iyi algılandığı bu çalışma ile ortaya konulmuştur. Sonuç olarak, herdem yeşil ağaç türlerinde, oval, eliptik ve tek tüysü yaprak şekline ve açık yeşil renge sahip yaprakların görsel olarak daha iyi algılandıkları belirlenmiştir. Bazı araştırmacılar (Acar ve ark., (2003); Müderrisoğlu ve ark. (2009); Kösa ve Atik (2013); Tarakçı Eren ve ark. (2018) bitkisel tasarımlarda bitkilerin genel görünüşlerinin veya bitkisel komposizyonların görsel algılanmasında yaprak renklerinin etkili olduğunu vurgulamaktadırlar. Ancak, yaprak rengi ve yaprak şeklinin birlikte görsel algıyı nasıl etkilediğine dair yapılmış bir çalışma yoktur. $\mathrm{Bu}$ çalışma, yaprak renklerinin algılanmasının yaprak şekli ile ilişkili olabildiğini ortaya koymaktadır. Bu bakış açısıyla bitkisel tasarımlarda, herdem yeşil ağaçların yapraklarının görsel algılanmasında yaprak renk ve şekil ilişkilerinin etkili olduğu bilgisi göz önünde bulundurulmalıdır.

Herdem yeşil türlerin yaprak renk ve şekil özelliklerinin bitkisel tasarımda, yaprak döken türlerin yapraksız olduğu kış mevsiminde diğer mevsimlere göre daha farklı etkiler yaratabileceği fikri bu çalışma öncülüğünde, başka çalışmalarla da desteklenmelidir.

\section{Kaynaklar}

1. Acar C, Demirbaş E, Dinçer P, Acar H (2003). Anlamsal Farklılaşım Tekniğinin Bitki Kompozisyonu Örneklerinde Değerlendirilmesi. Süleyman Demirel Üniversitesi Orman Fakültesi Dergisi, Seri A (1),15-28

2. Ak MK, Kaya S (2016). Düzce Üniversitesi Yerleşkesi Örneğinde Çim Alanların Görsel Alg1 Değerlendirmesi. Düzce Üniversitesi Ormancılık Dergisi, 12(2), 231-240.

3. Altman I, Wohlwill EJ (1983). Behavior And The Natural Environment. New York: Plenum Press. Isbn 0306- 41099-0.

4. Aydınlı S (1986). Mekansal Değerlendirmede Algısal Yargılara Dayalı Bir Model. DoktoraTezi, İ.T.Ü. Fen Bilimleri Enstitüsü, İstanbul.

5. Basıç G (2016). Bitkisel Tasarımda Estetik Ve Görsel Kalite. http://www.academia.edu/31351602/Peyzaj_Mimarlığında_Estetik_ve_Görsel Kalite. Erişim Tarihi: 11.09.2018

6. Çakcı I, Çelem H (2009). Kent Parklarında Görsel Peyzaj Algısının Değerlendirilmesi. Tarım Bilimleri Dergisi, 15(1), 88-95.

7. Düzenli T, Tarakçı Eren E, Baltacı H, Aktürk E (2018). Bitkisel Peyzaj Tasarımında Renk Tercihleri: Ktü Kanuni Kampüsü Örneği. Uluslararası Sosyal Araştırmalar Dergisi, 11(55),1082-1091.

8. Elinç H (2011). Görsel Kalite Değerlendirmesi Yöntemi İle Antalya İlialanya İlçesindeki Abdurrahman Alaettinoğlu ve Alanya Belediye Başkanları Kent Parklarının İrdelenmesi. Yüksek Lisans Tezi, Selçuk Üniversitesi, Konya.

9. Eroğlu E, Acar C (2018). A Visual Assessment of Roadside Poplar Plantings in Turkey. Journal of Agricultural Sciences, 24(2), 185-198.

10. Hemphill M (1996). A Note on Adults' Color-Emotion Associations. The Journal of Genetic Psychology, 157(3), 275-280. 
11. JuLan H, YannJou H (1998). The factors affecting visual preference of street trees on sidewalks. Journal of the Chinese Society for Horticultural Science ,44 (3),323-337.

12. Kaptanoğlu A (2006). Peyzaj Değerlendirmesinde Görsel Canlandırma Tekniklerinin Kullanıcı Tercihlerine Etkileri. Doktora Tezi, İstanbul Üniversitesi, İstanbul.

13. Kınık M, Öztürk MS (2017). Tipografik Tasarımda Rengin Okunurluğa Etkisi Konusunda Öğrenci Görüşlerinin İncelenmesi. Selçuk Üniversitesi Sosyal Bilimler Enstitüsü Dergisi, (37), 327-335.

14. Kösa S, Atik M (2013). Bitkisel peyzaj tasarımında renk ve form; çınar (Platanus orientalis) ve sığla (Liquidambar orientalis) kullanımında peyzaj mimarlığı öğrencilerinin tercihleri. Artvin Çoruh Üniversitesi Orman Fakültesi Dergisi, 14(1), 13-24.

15. Kurdoğlu B, Pirselimoğlu Z (2011). A Study for Semantic Evaluation of Street Trees. Artvin Çoruh Üniversitesi Orman Fakültesi Dergisi, 12 (2), 211-221.

16. Kurdoğlu BÇ, Üstün Topal T (2017). Aydınlatılmış kent parklarının kullanıcılar tarafindan değerlendirilmesi: Meydan parkı ve Atapark örnekleri. Artvin Çoruh Üniversitesi Orman Fakültesi Dergisi, 18(2), 137-151.

17. Küller R (1972). A Semantic Model for Describing Perceived Environment. National Swedish Building Research D. 12, Lund.

18. Müderrisoğlu H, Eroğlu E (2006). Bazı İbreli Ağaçların Kar Yükü Altında Görsel Algılanmasındaki Farklılıklar, Süleyman Demirel Üniversitesi Orman Fakültesi Dergisi, Seri: A, Sayı: 1, 136-146.

19. Müderrisoğlu H, Aydın G, Yerli Ö, Kutay E (2009). Effects of Colors and Forms of Trees on Visial Perceptions, Pakistan Jornal of Botany, 41 (6), 2697-2710.

20. Nasar LJ (1988). Environmental Aesthetıcs (Theory, Research And Applications). Usa: Cambridge University Press. Isbn 0-521 42916-1.

21. Osgood CE, May WH, Miron MS (1975). Cross-cultural Universals of Affective Meaning. Urbana: Universityof Illinois Press.

22. Öngen AG (2011). Görsel Tasarım Öğeleri Bağlamında Selçuklu Halıları (T.İ.E.M.'N deki Örnekler Üzerine Bir Araştırma). Yüksek Lisans Tezi, Marmara Üniversitesi Güzel Sanatlar Enstitüsü, İstanbul.

23. Özdemir T (2005). Tasarımda Renk Seçimini Etkileyen Kriterler. Çukurova Üniversitesi Sosyal Bilimler Enstitüsü Dergisi, 14(2), 391-402.

24. Polat AT, Akay A (2015). Relationships between the visual preferences of urban recreation areausers and various landscape design elements. Urban Foresty\&Urban Greening, 14, 573-582.

25. Sakıcı Ç, Ayan E, Özdiger ZP (2012). Differences in visual perception of Abies nordmannianasubsp. bornmulleriana Mattf under snow load. Kastamonu University Journal of Foresty Faculty, 12 (3 Special Iss.), 79-85.

26. Sakıcı Ç, Var M (2014). A Visual Perception Effect Assessment of Some Large and Broad-Leaved Trees Under Different Lighting Arrangements, Journal Architectural Science Review 57(2), 139-146.

27. Sanoff H (1991). Visual Research Methods in Design, Unfited States of America ISBN: 0-442-23827-4.

28. Sarı D, Karaşah B (2015). Hatila Vadisi Milli Parkı'nda (Artvin) Yer Alan Farklı Vejetasyon Tiplerinin Görsel Değerlendirmesi Üzerine Bir Çalışma Türkiye Ormancılık Dergisi, 16(1), 65-74.

29. Shafer EL, Jr Richards TA (1974). A Comparison of Viewer Reactions to Outdoor Scenes and Photographs of those Scenes. USDA Forest Service Research Paper, NE-302, Upper Darby, Pennsylvania. 1974.

30. Tarakçı Eren E, Alpak EM, Düzenli T (2018). Mevsimsel Bitki Görünümlerinin Tercih Ve Algısal Farklılıklarının Belirlenmesi. Uluslar Arası Bilimsel Araştırmalar Dergisi, 3(1), 145-154.

31. Tüfekçioğlu HK (2008). Tarihsel Çevrede Görsel Peyzaj Kalite Değerlendirmesi İstanbul Yedikule Örneği, İstanbul Teknik Üniversitesi Fen Bilimleri Enstitüsü, Peyzaj Mimarlığı Anabilim Dalı, Yüksek Lisans Tezi, İstanbul.

32. Zhao J, Xu W, Li R (2017). Visual preference of trees: The effects of tree attributes and seasons. Urban Forestry \& Urban Greening, 25, 19-25. 